\title{
Fishing strategies, economic performance and management of moored fishing aggregating devices in Guadeloupe
}

\author{
Olivier GUYADER ${ }^{1, a}$, Manuel BELlANGER ${ }^{1}$, Lionel REYNAL ${ }^{2}$, Sébastien DEMANÈCHE ${ }^{3}$ \\ and Patrick BERTHOU ${ }^{3}$ \\ 1 Ifremer, UMR AMURE, Unité d'Economie maritime, Département Ressources biologiques et Environnement (RBE), BP 70, \\ 29280 Plouzané Cedex, France \\ 2 Ifremer, Unité Biodiversité et environnement, Département Ressources biologiques et Environnement (RBE), 79 Route de Pointe-Fort, \\ 97231 Le Robert, Martinique \\ 3 Ifremer, Département Ressources biologiques et Environnement (RBE) Unité Sciences et Technologies halieutiques (STH) BP 70, \\ 29280 Plouzané Cedex, France
}

Received 23 April 2012; Accepted 8 February 2013

\begin{abstract}
Moored FADs (MFADs) have been a key area for development in Guadeloupe (Lesser Antilles) since the late 1980's. The main objectives underpinning the development of MFADs were to (i) reduce fishing pressure on coastal fishing resources; (ii) boost fishermen's incomes; and (iii) increase local consumption of locally generated fishery products as a proportion of overall consumption. This paper gives an overview of the current structure of Guadeloupe's fishing fleet and fisheries, with a specific focus on MFAD fleets in a relatively unstructured environment with regard to regulation, and so how these fleets operate in a context of unrestricted development of private MFADs. In addressing the following key issues, this paper aims to: assess the economic performance of fleets operating on MFADs, understand why the MFAD fishing activity has not developed more than it has, and suggest how better MFAD management could improve the situation. Socio-economic information on a trip and fleet level basis were collected and stored on a fisheries information system to analyse the relative attractiveness of MFAD fishing and assess the overall economic performance of MFAD fleets as compared to other non-MFAD fleets. Non-monetary variables were also tested to explain the degree of dependence on MFADs. In 2008, economic returns from FADs were relatively low, both in terms of wages for the crews and in terms of profit for vessel owners. Earnings were higher than coastal fishing activities, but seem to have been very sensitive to the indicators used in our analysis. MFADs are expected to become much more attractive as a result of MFAD regulation, especially through the establishment of collective MFADs.
\end{abstract}

Keywords: Moored FADs / Small-scale fisheries / Monetary and non monetary incentives / Economic indicators / Fishermen behaviour / Regulation / Caribbean sea

\section{Introduction}

Moored FADs (MFADs) have been a key area for development in Guadeloupe since the late 1980's. The main objectives underpinning the development of MFADs were to (i) reduce fishing pressure on coastal fishing resources; (ii) boost fishermen's incomes and; (iii) increase local consumption of locally generated fishery products as a proportion of overall consumption. Higher earnings were expected to result from increased numbers of catches of large pelagic species throughout the year, and reduced costs of travel and searching costs in particular, as compared with the costs of troll fishing on free swimming schools. This higher earning potential was also expected to give fishermen economic incentives to switch from over-exploited coastal fisheries to MFAD fisheries (Reynal and Taquet 2002). Growth in large pelagic landings

\footnotetext{
a Corresponding author: oguyader@ifremer.fr
}

was also supposed to supply local markets and reduce the dependency of the islands on seafood imports. Until recently, Guadeloupe's fisheries policy was based on a weak regulatory system that - in practice - allowed free establishment of private MFADs. According to Marine Fisheries Regulations ${ }^{1}$, permission to set up an FAD must be obtained prior to its installation, and the exact positioning of the FAD must be registered once it is in place. However, to date there is no system for judicious planning of the positioning of FAD's, nor are there any specific rights associated with any particular territorial usage (Christy 1982). The rights to own and exploit an FAD are only granted to professional fishers. The FAD owner has priority of exploitation within a radius of a quarter of a nautical mile around a FAD. In the absence of FAD owner,

\footnotetext{
${ }^{1}$ French Regional (Prefecture) Statute No. 2002/1249 dated 19 August 2002 regulating marine fisheries in Guadeloupe. Title III, Article 47.
} 
any commercial fisherman is entitled to exploit the FAD. The regulation makes no mention of any restrictions on the type of fishing technique that can be used on the FAD. While the authorized mesh size used with fishing gear is stipulated for other fisheries, most island fisheries on the continental shelf can be considered to be "open-access". Public funding to encourage investment in vessels and engines was also allocated in the context of the Common Fisheries Policy. While the number of vessels involved in MFAD fisheries increased during the 1990s, the sector's development appears to have levelled against a background of uncertainties regarding the evolution of fuel prices and MFAD management. The main questions addressed in this paper are the assessment of economic performance of fleets operating on MFADs, an attempt to understand barriers and enabling factors to MFAD fishing in Guadeloupe.

Little research has been done to assess the economic situation of small-scale fleets and to analyse the economic benefits of FADs (Rey-Vallette et al. 2000; Failler and Kroese 2011; see also Dempster and Taquet 2004 for a more recent review of the literature). This is probably due to a lack of FAD fisheries monitoring, but the issue is broader. It concerns most small-scale fisheries around the world (Chuenpagdee et al. 2006; Garcia et al. 2008) or in Europe (Guyader et al. 2007). However, poor data contexts are considered to be barriers to the sustainable management of fisheries, and especially in the Caribbean (Salas et al. 2007). To improve the situation, the prevailing view is that we need to go beyond the analysis of landings to explore fishing strategies, fleet dynamics and their socioeconomic situation (Seijo et al. 1994; Cabrera and Defeo 2001; Salas and Gaertner 2004; Defeo and Castilla 2005). This recommendation is particularly true of MFAD fisheries where fishing strategies and effort allocation between fisheries can be influenced by the establishment of MFADs. The dynamics of FAD fisheries cannot be understood without taking into account the economic situation of other fisheries, especially in small-scale contexts where vessels are often multi-purpose, and so may switch from one fishing activity to another according to their relative attractiveness. While it is true that the opportunity cost of fishing (i.e. the value of the next best alternative forgone in the island economy) is difficult to measure, it should always be taken into account in such an analysis.

This paper gives an overview of the current structure of the fleet and fisheries in Guadeloupe with a specific focus on MFAD fleets. It details the methodologies established to collect socio-economic information on a trip and fleet level basis. We then analyse the opportunity cost of MFAD activity and assess the overall economic performance of MFAD fleets as compared with other non-MFAD fleets using monetary indicators. Non-monetary variables are also tested to explain the degree of dependence on MFADs. Results are discussed in relation to MFAD management issues, especially the establishment of collective MFADs.

\subsection{Guadeloupe fisheries, and fleet and gear strategies}

Located in the Lesser Antilles (FAO area 31), Guadeloupe is an overseas department of France comprising the islands of
Grande-Terre and Basse-Terre, and several smaller islands in the Leeward Islands. Fishing activity is constrained by the narrow island shelves, the main species caught being reef fish, crustaceans and small pelagic species (Blanchet et al. 2002; Gobert and Reynal 2002). Pots, gillnets, trammel nets, encircling nets and hooks and lines are the main gears used. Large pelagic species - mainly dolphin fish, tuna and marlin - are harvested offshore using trolling and vertical longlines, either on free-swimming schools or around MFADs (Diaz 2002a). In 2008, 878 small-scale vessels were registered in Guadeloupe. Their average length and engine power were $7.2 \mathrm{~m}$ and $170 \mathrm{HP}$ respectively (Leblond et al. 2010). Most of the vessels were less than $12 \mathrm{~m}$ in length, open-decked with outboard engines, and mainly fishing in the context of one-day fishing trips.

A Fisheries Information System (FIS) was established in 2007 to improve data collection and knowledge about Guadeloupe fisheries. In the context of an exhaustive fleet field survey, the fishing calendars of each vessel were collected (Berthou et al. 2008). A fleet segmentation was also carried out to group together vessels having the same fishing strategies, and therefore relatively homogeneous economic behaviour that could be tracked over time (Guyader et al. 2008). This fleet segmentation was then used so that fleet fishing effort (i.e. days at sea) could be allocated between fishing gears (Guyader et al. 2011). This type of information required by Data Collection Regulation (EC 2008) to evaluate the situation of the fishing sector under the Common Fisheries Policy is presented hereafter. Of the 767 active vessels, 282 units were involved in MFAD fishing in 2008, but only one fleet (hook and line FADs) of 61 vessels targeted exclusively large pelagic species. The other FAD fleets combined FAD fishing with other coastal gears (pots, nets, etc.) either singly or in combination. For example, hook and line FAD potters share their fishing effort between pots and FADs for around 2200 days at sea. In 2008, the FAD activity represented around 12000 days at sea, and so $19 \%$ of the total number of days at sea for the whole fleet. However, the gear used most was pots (17500 days at sea) and the third most used gear after FAD was gillnets with around 9000 days at sea. Trolling (6500 days) is a seasonal activity targeting dolphin fish from December to May. Other fleets use only coastal gears, and Guyader et al. (2011) provided a detailed description of their relative importance (Annex 1). Guyader et al. (2011) also estimated total landings at 3900 tons for a total value of $€ 33 \times 10^{6}$ in 2008 , and MFAD fishing accounted for $28 \%$ and $25 \%$ of landings in quantity and value respectively.

From this, we can see that it is difficult to follow the evolution of MFAD fisheries without considering the economic performance of other strategies, given the possibility for fishing units to switch from one type of gear to another. The possibility of switching gear is probably not homogenous between vessels, but this approach has confirmed the usefulness of a better monitoring of these strategies through relevant data collection.

\section{Materials and methods}

With due consideration to take the poor data context of Guadeloupe fisheries into account, sampling strategies were established to collect relevant socio-economic information at 
Table 1. Sampling of fishing trips in 2008.

\begin{tabular}{lcc}
\hline & $\begin{array}{c}\text { Number } \\
\text { of trips } \\
\text { sampled }\end{array}$ & $\begin{array}{c}\text { Sampling } \\
\text { rate }\end{array}$ \\
\hline Pots & 1005 & $5.7 \%$ \\
Hook and line FADs & 410 & $3.4 \%$ \\
Gillnets & 367 & $4.0 \%$ \\
Trolling line & 259 & $3.9 \%$ \\
Hook and line & 124 & $3.4 \%$ \\
Encircling net & 60 & $2.1 \%$ \\
Deep longlines & 31 & $1.4 \%$ \\
Trammel net & 125 & $5.9 \%$ \\
Longlines & 19 & $1.0 \%$ \\
Deep pots & 52 & $2.7 \%$ \\
Spearfishing & 145 & $12.0 \%$ \\
Purse seine & 98 & $10.6 \%$ \\
Other gillnets & 69 & $8.8 \%$ \\
Deep gillnets & 19 & $5.6 \%$ \\
Others & 140 & $28.5 \%$ \\
Total & 2923 & $4.6 \%$ \\
\hline
\end{tabular}

Source: Ifremer-SIH-Obsdeb and DPMA.

fishing gear and segment levels. These sampling strategies were designed on the basis of the census carried out for the whole fleet (Berthou et al. 2008). Based on the data collected, a statistical analysis was also carried out to test the influence of non-monetary variables on the vessel's economic dependence on FADs. This is to test the influence of economic, social and cultural drivers on the behaviour of fishermen (see Marchal et al. 2009 and Fulton et al. 2011 for a more general discussion of this issue in fisheries management).

\subsection{Fishing trip sampling including economic information}

Fishing trip sampling was organized to cover the different landing sites and fishing gears including fishing on MFADs. A major constraint for the establishment of a data collection strategy was the high number of landing points (77 in total). Sampling methodology described by Demanèche et al. (2008) was carried out to optimise the allocation of the sampling effort throughout the year according to the intensity of the activity at each landing point or group of landing points, and the diversity of gears used. Data collected at vessel trip level included information on gears used, landings per species, effort per trip (time at sea, number and size of gears). Vessel characteristics and crew size, but also economic information such as species price and fishing trip costs (gas, oil, bait, food, landing costs) were collected by a team of four observers. In 2008, three days per week were devoted to fishing trip sampling. The number of trips and the percentage of total trips sampled for each gear are available in Table 1.

Around $5 \%$ of the total estimated number of trips were sampled in 2008 (Guyader et al. 2011). MFAD trips represent $14 \%$ of the total number of trips, and $3.4 \%$ of the total estimated number of MFAD trips. The other main fishing
Table 2. Distribution of the economic sample per segment.

\begin{tabular}{lcc}
\hline Fleet segment/Gear & $\begin{array}{c}\text { Number } \\
\text { of vessels }\end{array}$ & $\begin{array}{c}\text { Sampling } \\
\text { rate }\end{array}$ \\
\hline Multipurpose fixed gears & 126 & $13.5 \%$ \\
Hook and line FADs- & 100 & $21.0 \%$ \\
Multipurpose fixed gears & & \\
Potters & 84 & $15.5 \%$ \\
Trollers-Multipurpose & 73 & $11.0 \%$ \\
fixed gears & & \\
Hook and line FADs-potters & 63 & $15.9 \%$ \\
Hook and line FADs & 61 & $8.2 \%$ \\
Trollers-potters & 41 & $19.5 \%$ \\
Gillnetters & 38 & $23.7 \%$ \\
Hook and line FADs- & 34 & $20.6 \%$ \\
hook and long liners & & \\
Encircling net-purse seiners & 33 & $12.1 \%$ \\
Trollers-gillnetters & 27 & $14.8 \%$ \\
Hook and line FADs-gillnetters & 24 & $12.5 \%$ \\
Hook and long liners & 38 & $7.9 \%$ \\
Trollers-hook and long liners & 14 & $7.1 \%$ \\
Trollers & 11 & $9.1 \%$ \\
Total & 767 & $14.9 \%$ \\
\hline
\end{tabular}

$\square$ FAD fleet segment $\backslash$ Gear. Source: Ifremer-SIH-Economie.

gears - pots, trolling lines and gillnets - were sampled at $5.7 \%$, $3.9 \%$ and $4.1 \%$ respectively.

\subsection{Socio-economic survey}

A socio-economic survey was also established in 2008 to complete the information gathered through fishing trip sampling. The objective was to get economic data from a sample of vessels representative of the different segments. The sampling strategy used for vessel sampling selection was similar to the one developed for mainland France (Van Iseghem et al. 2011). The questions were based on a monetary approach that also includes social indicators. The questionnaire consists of nine main sections in logical order; surveys are conducted with vessel owners about their fishing activities, their related earnings and costs, and more specifically, on the characteristics of their fishing vessel. The latter includes the type of hull, engine, fishing gear, electronic equipment, and the related costs.

Technical documents (in French) describing the methodology, from sampling optimization to the questionnaire, and the software used to record the information collected are available on the IFREMER website http://www.ifremer.fr/sih/. Interviews took place between February and June in 2009 to collect economic data for 2008. One hundred and fourteen questionnaires were collected, representing a survey conducted on around $15 \%$ of the total fleet (Table 2). Considering the limited size of the sample for some segments and the heterogeneity of results between vessels size, samples were merged to distinguish FAD from non-FAD fleets and vessel categories $(<7 \mathrm{~m}$ and $\geqslant 7 \mathrm{~m}$ ).

Data collected from the economic survey were validated vessel by vessel and variable by variable in several stages, including tests on quality, consistency, and continuity between 
variables. All economic variables were compiled in accordance with the definitions in Appendix VI of EC (2008).

\subsection{Statistical analysis of vessel's economic dependence on FADs}

Within economic indicators, the degree of economic dependence on FADs is a more precise indicator to study. It is calculated as the percentage of FAD revenue in relation to the total gross revenue of each vessel. A statistical analysis was carried out on the population to test the influence of nonmonetary variables such as the type of harbour each vessel was attached to, the vessel owner's age, vessel size, crew size, and trimesters worked on FADs on the vessel's economic dependence on FADs. Harbour types studied ranged from harbours with a narrow to a large insular shelf, to test the influence of fishing potential in coastal areas. The age of the vessel owner is a variable that may manifest different behaviours: fishing habits and a certain inertia on the part of the oldest fishermen to adopt new techniques such as FADs, reluctance of the oldest fishermen to operate certain techniques because of their health hazards all may have an impact. The influence of age can also be positive if the experience plays a significant role in the adoption and practice of a fishing activity. Vessel size and crew size are of interest because FADs may require bigger vessels and a larger crew to operate on the more distant MFADs. Finally, the trimesters the vessel worked on FADs was included as a variable to test whether the degree of dependence could be explained by seasonal fishing patterns.

We looked at each variable separately when considering them as factors. Numerical variables were converted into categorical variables. In the first instance, we wanted to identify which variables have a significant influence on whether or not vessels have a nonzero dependence on FADs. We used the $\chi^{2}$-test for this purpose. The null hypothesis of the test is (H0), the factor does not influence the percentage of vessels having a nonzero dependence on FADs. Studying the way factors interact can also be a useful line of enquiry, but this requires estimation of a lot more parameters. Moreover, there are some combinations of factors for which there are only a very few vessels. Therefore, for the purposes of our study, the analysis of interactions was not pursued.

Another essential aim of our study was to explain the variability in percentage of FAD revenue in relation to total revenue for the vessels that are dependent on FADs (i.e. vessels with a percentage greater than 0). For this investigation we analysed variance with the same factors as we used in the previous analysis, which are harbour type, owner age, vessel size, crew size and trimesters. In our analysis of variance, the F-test was used to test the null hypothesis (H0), which is: the mean percentage of FAD revenue in relation to total revenue is the same within each group.

\section{Results}

Different fishing trip indicators such as quantity and value (i.e. gross revenue) of landings per trip, the gross added value per trip, the trip duration and the gross added value per crew member per hour at sea and per trip are presented in Figures $1 \mathrm{a}-\mathrm{g}$. Landings per trip are often used to exhibit the positive impacts of MFAD on small-scale fisheries. Indeed, such an indicator often shows that landings per unit effort are more important in FAD large pelagic fisheries than in coastal fisheries. This is also true in the case of Guadeloupe, where mean MFAD landings were around $100 \mathrm{~kg}$ per trip in 2008. These amounted to $35 \mathrm{~kg}$ for pots and $45 \mathrm{~kg}$ for gillnets, the principal other gear used in the insular shelf (Fig. 1a). Landings value is more relevant as it takes into account species prices. The gap between MFAD fisheries and other fisheries is reduced because of the relatively lower prices of dolphin fish, tuna, and marlins compared to snappers, groupers and crustaceans targeted by pots and nets (Fig. 1d). While variable costs, and especially fuel costs, are quite significant for MFADs (€140) and not very different from trolling line fishing on free-swimming schools, they are clearly higher than for pots and gillnets ( $€ 40$ and $€ 50$, Fig. 1c).

Gross added value per trip is more appropriate for the purpose of explaining fishermen's behaviour because it includes the gross revenue, but also the costs - operating expenses such as fuel, bait, gears, repairs and maintenance - associated with operating each type of gear ${ }^{2}$. While FADs offer the advantage of higher gross added value, the differentials between gears rapidly reduce with figures of $€ 480, € 220$ and $€ 265$ for FADs, pots, and gillnets respectively (Fig. 1e). However, distributions overlap and this may explain why fishermen decide not to operate systematically on FADs.

Differences in trip duration are also significant (Fig. 1b). Time at sea is around $10 \mathrm{~h}$ for FADs and trolling lines, while it is only $4 \mathrm{~h}$ for pots and gills nets. Gross added value per trip and per fisherman was calculated to integrate trip duration but also the effects of crew size. The benefit of FADs compared to other types of gear is reversed when the mean figures are taken into consideration: $€ 22$, $€ 29$ and $€ 44$ for FADs, pots, and gillnets respectively (Fig. 1g). The differences between these mean values are statistically significant.

These indicators can be used to address the issue of the opportunity fishing cost (i.e. the value of the next best alternative the island community has foregone in order to pursue the current opportunity). If the opportunity cost of fishing is zero or low for fishermen, they are more likely to act on the basis of an added-value-per-trip comparison, without any consideration of trip duration issues. In this case, results show that it will be advantageous to fish on FADs rather than with coastal gears, because the net income per trip will be higher (Fig. 1f). If the opportunity cost of time spent fishing is not negligible, and represents a serious (economically advantageous) alternative to fishing, then fishing with coastal gears for part of the day plus having another economic activity the rest of day may become more interesting than MFAD fishing for a whole day. Even if the income from the other economic activity is uncertain and difficult to estimate, one thing that is certain is that gross added value per crew member per hour is higher for coastal gears fishing than MFAD fishing (Fig. 1g), and this may explain the relative attractiveness of the former as compared to the latter.

2 Repairs and maintenance cost were allocated to trip costs per gear in proportion to the gross revenue per gear. 
a. Landings

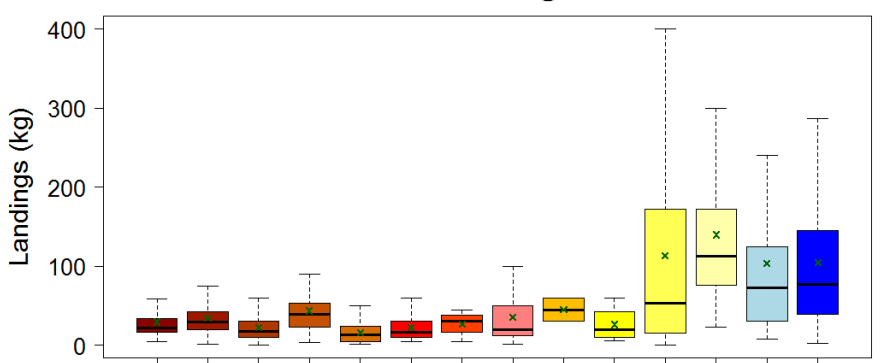

c. Total variable costs

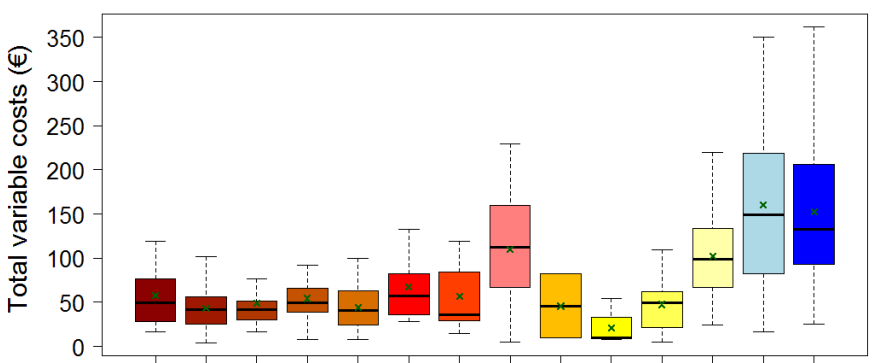

e. Value added

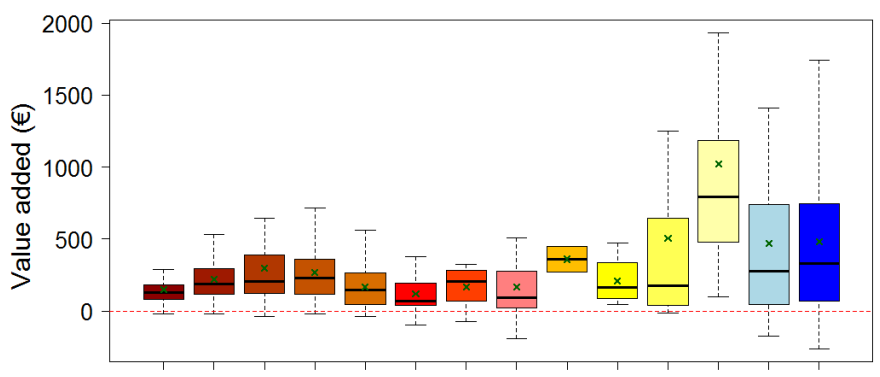

b. Trip duration

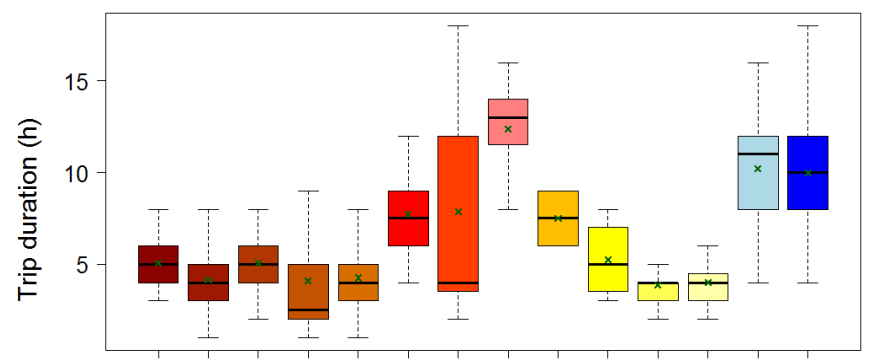

d. Gross revenue

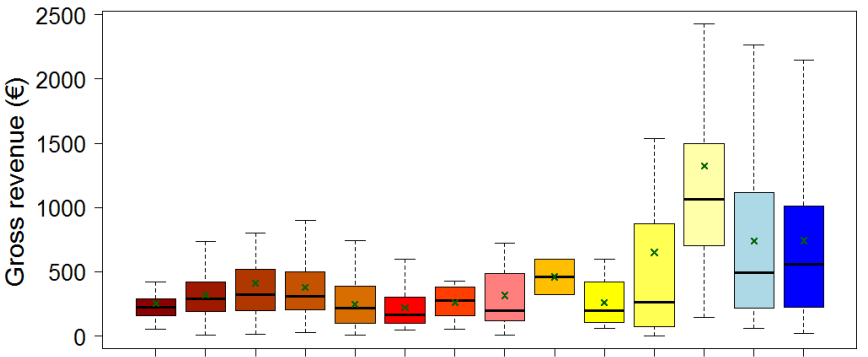

f. Value added per crew member

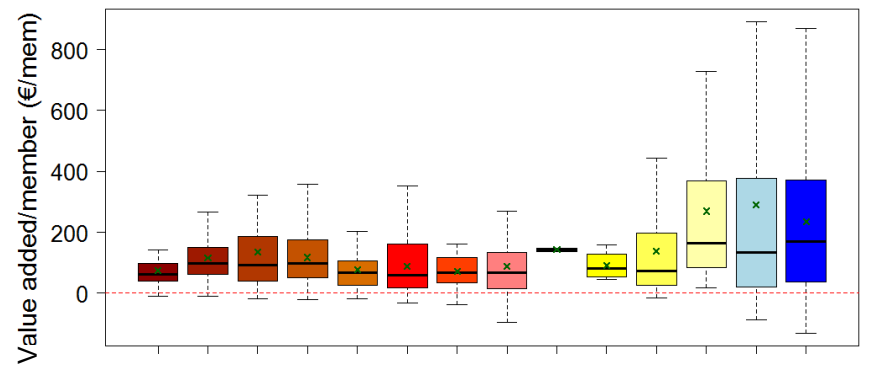

g. Value added per crew member and per hour at sea

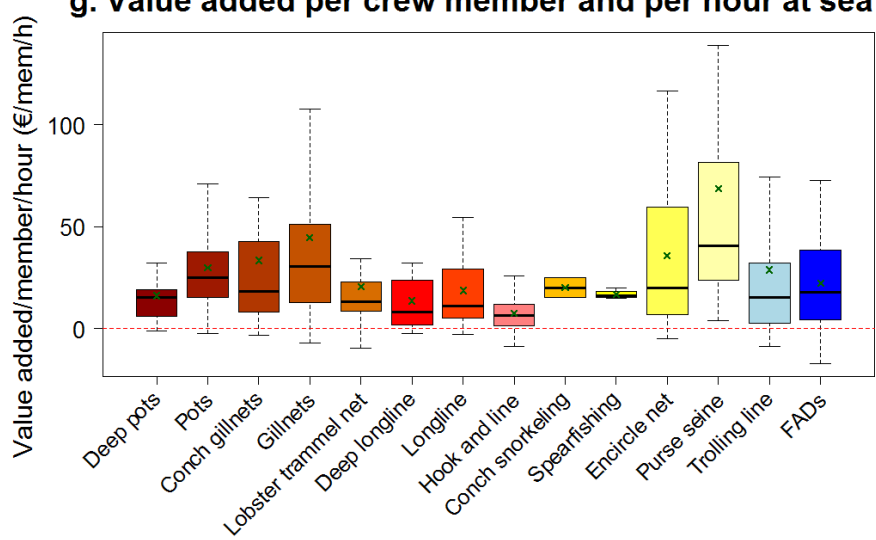

Fig. 1. Fishing trip indicators for moored FAD and non-MFAD gears, $(\times)$ in boxplots indicate the mean value of the distribution for the different gears (source: Ifremer-SIH-Obsdeb-Economie).

From this, one can easily understand why the choice of FAD activity and the intensity of this activity are not homogeneously distributed within the fleet. This has been described through the identification of the different FAD fleet segments (Annex 1).

Non-monetary incentives can also be seen to influence fishermen's behaviour. The results of the statistical analysis carried out to test the influence of different variables on the vessel's economic dependence on FADs are as follows. For harbour types, owner age and vessel size, the $\chi^{2}$-test turned out to be significant, which means that these variables have a significant influence on whether or not a vessel belongs to an FAD-related fleet. On the other hand, the $\chi^{2}$-tests performed on crew size and trimesters worked on FADs were not significant. In order to estimate the relative effect of each level of a significant factor on whether or not a vessel is dependent on 
Table 3. Estimation of relative effects of owner age groups (increase in the mean rate of vessels dependent on FADs in comparison with the global mean rate). $N$ : number of owners.

\begin{tabular}{ccc}
\hline $\begin{array}{c}\text { Owner age } \\
\text { groups }\end{array}$ & $N$ & $\begin{array}{c}\text { Comparison } \\
\text { with global } \\
\text { rate }\end{array}$ \\
\hline$] 20-25]$ & 5 & $+42.6 \%$ \\
] $25-30]$ & 37 & $+30.2 \%$ \\
] $30-35]$ & 78 & $+8.8 \%$ \\
] $35-40]$ & 111 & $+11.3 \%$ \\
] $40-45]$ & 138 & $+1.8 \%$ \\
] $45-50]$ & 131 & $-2.3 \%$ \\
] $50-55]$ & 123 & $-11.4 \%$ \\
] $55-60]$ & 55 & $-13.7 \%$ \\
$>60$ & 47 & $-22.5 \%$ \\
\hline
\end{tabular}

Total number of owners: 725 .

Table 4. Estimation of relative effects of vessel size groups (increase in the mean rate of vessels dependent on FADs in comparison with the global mean rate). $N$ : number of owners.

\begin{tabular}{ccc}
\hline $\begin{array}{c}\text { Vessel size } \\
\text { groups }\end{array}$ & $N$ & $\begin{array}{c}\text { Comparison } \\
\text { with global } \\
\text { rate }\end{array}$ \\
\hline$<7 \mathrm{~m}$ & 278 & $-9.1 \%$ \\
$\geqslant 7 \mathrm{~m}$ & 447 & $+5.6 \%$ \\
\hline
\end{tabular}

Total number of owners: 725 .

FADs, one can compare the rate of vessels dependent on FADs for each level with the global rate (Tables 3 and 4).

We see that the younger the owner, the higher the probability that the vessel will be dependent on FADs. Another conclusion drawn is that the bigger the vessel, the higher the probability that the vessel will be dependent on FADs. Small vessels can operate on FADs, but the development of FADs in Guadeloupe has led to an increased requirement in parallel for larger vessels on the part of remote MFAD fisheries. Similar results were obtained for harbour types showing that vessels belonging to harbours with narrow insular shelves are also more likely to be dependent on FADs.

We analysed variance with the same factors as we used in the previous analysis to explain the variability in percentage of FAD revenue in relation to total revenue for the vessels that are dependent on FADs (i.e. vessels with a percentage greater than 0). For each model that we built, the F-test was not significant, with the result that we could not reject the null hypothesis. In other words, the variables that were useful for determining whether a vessel was dependent on FADs were not relevant when it came to explaining the variability of the percentage of FAD revenue in relation to total revenue for the FAD-dependent vessels.

As indicated earlier, economic performance indicators were calculated for a segmentation that distinguishes between vessel size $(<7 \mathrm{~m}, \geqslant 7 \mathrm{~m})$ and whether the vessel makes use of MFADs or not. Most of the vessels using MFADs are multipurpose vessels, as we highlighted earlier, and the degree of dependence was calculated for each segment (Table 5). The degree of dependence is around 53\% for FAD vessels $\geqslant 7 \mathrm{~m}$ and $27 \%$ for vessels under $7 \mathrm{~m}$, and null for the other segments
Table 5. Fleet characteristics and dependence on FADs.

\begin{tabular}{lcccc}
\hline & \multicolumn{2}{c}{ Coastal vessels } & \multicolumn{2}{c}{ FAD vessels } \\
& $<7 \mathrm{~m}$ & $\geqslant 7 \mathrm{~m}$ & $<7 \mathrm{~m}$ & $\geqslant 7 \mathrm{~m}$ \\
\hline Sample size & 24 & 20 & 22 & 48 \\
Length (m) & 6.0 & 8.0 & 6.4 & 7.9 \\
Engine power (kW) & 61 & 162 & 91 & 169 \\
Year of construction & 1992 & 1998 & 1997 & 2001 \\
Crew size & 1.8 & 2.1 & 1.9 & 2.1 \\
Days at sea & 130 & 153 & 117 & 143 \\
Dependence on FADs (\%) & 0 & 0 & 27 & 53 \\
Capital value per crew & 2410 & 11699 & 6235 & 19304 \\
member (€) & & & & \\
Vessel subsidies & 3 & 9 & 11 & 19 \\
(\% of investment cost) & & & & \\
Engine subsidies (\% of & 7 & 4 & 8 & 14 \\
investment cost) & & & & \\
\hline
\end{tabular}

Total sample size: 114 fishing vessels.

Source: Ifremer-SIH-Activité-Economie-Obsdeb, DPMA.

operating only on coastal gears. Vessel characteristics are similar between vessels larger than $7 \mathrm{~m}$, and the difference is more pronounced for MFAD vessels of less than $7 \mathrm{~m}$ that were built more recently. Higher levels of vessel activity (in terms of number of days at sea) are recorded for larger vessels than for smaller ones, whatever the segment. Crew size is more related to vessel length than to the vessel's dependence on FADs. FAD vessels are still small-scale if we consider the capital per crewmember as an indicator of capital intensity. Fleet policy development has resulted in more powerful vessels and a higher capital unit cost. A share of this additional investment cost was borne by public subsidies for vessel construction and engine replacement, but the former (i.e. construction subsidies) were frozen in 2004 at EU level.

One important difference between FAD vessels and others is the level of state aid available, and especially vessel subsidies, which increase with vessel size and dependence on FADs. This accounts for $19 \%$ of the investment costs for FAD vessels larger than $7 \mathrm{~m}$, and less than $3 \%$ for coastal vessels less than $7 \mathrm{~m}$. This is probably the result of EU structural policy over the last 20 years and the way policy is rolled out at regional level, as it effectively gave priority - through selective vessel subsidies - to the development of FADs. The percentage of subsidy allocated to engine replacement is much lower, and more dispersed among fleets. The subsidies rate on capital is not negligible, but the cost of capital is relatively low compared to the cost of intermediate consumptions (fuel, gears, etc.). As a consequence, the impact of subsidies on the economic performance of fishing firms is quite limited, despite the fact that subsidies could have given fishermen incentives to invest in new vessels.

At $€ 75 \times 10^{3}$, and $€ 52 \times 10^{3}$ per vessel, the average gross revenues per year of the $\geqslant 7 \mathrm{~m}$ and $<7 \mathrm{~m}$ FAD fleets are $40 \%$ and $50 \%$ higher respectively than the non-FAD fleets of the same sizes. This confirms the FAD vessels' capacity to generate higher revenues compared to other fishing activities. The analysis of the cost structure highlights significantly higher fuel and gear costs as compared with other French small-scale fleets (Daurès et al. 2009; Van Iseghem et al. 2011). Fuel costs 
Table 6. Fleet economic indicators (mean values in $€$ per days at sea).

\begin{tabular}{lcccc}
\hline & \multicolumn{2}{c}{ Coastal vessels } & \multicolumn{2}{c}{ FADs vessels } \\
\cline { 2 - 5 } & $<7 \mathrm{~m}$ & $\geqslant 7 \mathrm{~m}$ & $<7 \mathrm{~m}$ & $\geqslant 7 \mathrm{~m}$ \\
\hline Gross revenue & 289 & 330 & 447 & 526 \\
Fuel cost & 35 & 49 & 54 & 82 \\
Bait, ice, etc. & 10 & 10 & 23 & 23 \\
Gears cost (inc. FADs) & 45 & 54 & 70 & 85 \\
Repairs, maintenance, etc. & 8 & 12 & 14 & 20 \\
Total intermediary consumptions & 98 & 125 & 161 & 210 \\
Gross added value & 190 & 205 & 286 & 316 \\
Crew cost & 153 & 160 & 228 & 279 \\
Wage per crew member & 85 & 74 & 118 & 136 \\
Vessel gross surplus & 37 & 45 & 58 & 37 \\
Full equity profit & 34 & 38 & 53 & 27 \\
Owner operator's income & 117 & 107 & 166 & 155 \\
\hline
\end{tabular}

Sample size: 114 fishing vessels.

Source: Ifremer-SIH-Activité-Economie-Obsdeb.

range from $12 \%$ for vessels $<7 \mathrm{~m}$, to $16 \%$ for the vessels $\geqslant 7 \mathrm{~m}$, whatever the fleet segment. Gear costs are quite similar throughout the fleets, corresponding to $15-16 \%$ of gross revenue. Repairs, maintenance and other costs are low (3-4\%), and low also in relation to the small-scale nature of the invested capital. The intermediate consumption ratio is lowest for the smallest coastal fishing units (34\%), and increases with the size and degree of dependence on FADs, but only to a maximum of $39 \%$. It is also interesting to note that the share of fixed costs in intermediate consumption is very low, which is often a characteristic of small-scale fisheries (Guyader et al. 2007; Guyader et al. 2013). One other interesting result is that the differences in scale for the added value indicator are quite similar to the differences in scale for gross revenue.

As a proportion of the gross added value, crew cost (80-88\% for the fleets most dependent on FADs) is the most important economic indicator reflecting the labour intensive nature of the activity. The average net wage per crew and per trip is $€ 120$ and $€ 135$ per day at sea $\left(€ 13.8 \times 10^{3}\right.$ and $€ 19.3 \times 10^{3}$ per year) for the $<7 \mathrm{~m}$ and $\geqslant 7 \mathrm{~m}$ FAD fleets, as compared with $€ 85$ and $€ 74\left(€ 11.1 \times 10^{3}\right.$ and $€ 11.4 \times 10^{3}$ per year) for non-FAD fleets (Table 6). These figures can be compared to the minimum conventional wage in the French economy which was around $€ 50$ per day $\left(€ 12.9 \times 10^{3}\right.$ per annum) in 2008. The differentials in wages per day at sea are especially significant for FAD vessels, but the gap is reduced and inverted for non-FAD vessels when the number of days at sea per year is considered. Being more or less active is therefore crucial to determining the economic performance of vessels. Vessel gross surplus is between $12 \%$ and $20 \%$ of gross added value, but these results must be analysed carefully as the skipper is in most cases the owner of the vessel. The owneroperator is rewarded both through the crew share, in their capacity as a member of the crew, and through the residual profit as the owner of the vessel. In such a situation, Boncoeur et al. (2000) recommend using the owner-operator's income as indicator because it is so difficult to separate out wages from profits. The skipper owner-operator income is $45 \%$ higher for FAD vessels compared with non-FAD vessels.

\section{Discussion and conclusion}

The analysis of economic indicators at fleet and trip levels for MFAD and non-FAD related fishing activities highlights new results with respect to MFAD management, and more generally for fisheries management in Guadeloupe. In 2008, the economic returns from FADs were not very high, both in terms of wages for crews and profits for vessel owners. Our results are based on data collected over one year only, and so have to be treated with caution because MFAD catches are dependent on large pelagic species, that are renown for their variability. Economic performance for MFAD-based fishing activity was, however, higher than for coastal fishing activities, but this has to be viewed in perspective. This difference increases with the level of vessel activity, suggesting that performance could be improved if vessels were more active.

One also has to consider that the relative benefits of MFADs are lowered when time at sea is included is the analysis. In the light of this, one might conclude that it would be more profitable to operate using coastal gears for part of the day's fishing, and then exercise another business activity altogether for the rest of the day, rather than fish offshore on FADs for a full day at a time. However distributions in economic returns overlap, and this may explain why fishermen decide not to operate systematically on FADs. This is probably due to seasonal patterns, or to catch variability, which is a current issue for large pelagic species. The fact remains that negative margins are more frequently encountered for FAD fishing gears than for other fishing gears, and this is considered a serious problem in terms of the attractiveness of MFADs. Moreover, successive low catches and high trip costs are sometimes experienced by fishermen, and the resulting cash flow problems may negatively impact incentives to develop fishing effort on MFADs in such a context.

Vessel harbour location around the islands is one factor explaining the vessels' involvement in MFADs, as well as nonmonetary variables such as vessel owner age and vessel size. Working conditions and safety at sea are probably the main factors explaining this trend (Diaz et al. 2006). FAD fishing generates new risks in relation to the boats and gear used, with consequences on the safety of fishing operations and the health of crews (Andro et al. 1994).

It is clear that the way MFADs are managed or not managed can influence how fishing vessel owners behave, and this in turn affects the economic performance of their fishing units. Taking this one stage further, weak regulation governing access to MFADs in Guadeloupe has favoured the non-controlled development of private MFADs. While vessel owners are obliged to declare the setting up of MFADs to the local administration, they have always been at liberty to set up MFADs freely and where they want. Guyader et al. (2011) identified a very high density of MFADs around Guadeloupe and the related fishing strategies they identified are characterised by successive visits to a large number of MFADs during a fishing trip. A visit is usually associated with a particular fishing operation, but the time spent fishing on individual MFADs is limited by the fact that fishermen visit several MFADs within a trip. This kind of fishing behaviour differs significantly from typical behaviour in nearby Martinique island where fishermen remain most of the day around one or two MFADs. 
Annex 1. Days at sea per fleet segment and gears. In grey: FAD fleet segments. Estimated number of days at-sea per fleet segment and per fishing gear, e.g., Multipurpose fixed gears - 437 days at sea for deep pots (after Guyader et al. 2011).

\begin{tabular}{|c|c|c|c|c|c|c|c|c|c|c|c|c|c|c|c|c|c|c|c|c|}
\hline \multicolumn{21}{|l|}{ Fleet segments $\backslash$ Gears } \\
\hline Multipurpose fixed gears & 126 & 437 & 3545 & 13 & 119 & 2535 & 654 & 597 & $\overrightarrow{708}$ & $\overrightarrow{751}$ & 115 & 26 & 60 & & 270 & 4 & & 83 & & 10043 \\
\hline Hook and line FADs-Multipurpose fixed gears & 100 & 92 & 1603 & 28 & 146 & 1050 & 258 & 273 & 238 & 342 & 100 & 35 & 16 & & 117 & & & 3332 & 114 & 8770 \\
\hline Potters & 84 & 654 & 5262 & 0 & 8 & 52 & 22 & 29 & 20 & 24 & 501 & 110 & 48 & & 199 & 2 & & 5 & & 6993 \\
\hline Trollers-Multipurpose fixed gears & 73 & 170 & 1800 & 155 & 126 & 1122 & 265 & 382 & 364 & 503 & 19 & 0 & 0 & & 123 & 2 & & 179 & 126 & 6502 \\
\hline Hook and line FADs & 61 & 17 & 57 & 0 & 1 & 28 & 14 & 29 & 0 & 8 & 0 & 0 & 0 & & 0 & & & 3854 & 12 & 5224 \\
\hline Trollers-potters & 41 & 449 & 2865 & 5 & 9 & 7 & 16 & 9 & 13 & 69 & 90 & 0 & 0 & & 0 & 3 & & 165 & 47 & 4205 \\
\hline Gillnetters & 38 & 0 & 39 & 0 & 164 & 2936 & 297 & 0 & 74 & 72 & 0 & 48 & 18 & & 318 & 2 & & 48 & & 4061 \\
\hline Hook and line FADs-hook and long liners & 34 & 15 & 66 & 0 & 6 & 0 & 49 & 364 & 132 & 559 & 2 & 0 & 2 & & 0 & & & 1256 & 33 & 2789 \\
\hline Encircle net-purse seiners & 33 & 0 & 26 & 0 & 2 & 91 & 1 & 0 & 3 & 16 & 1543 & 589 & 20 & & 0 & & & 17 & & 2391 \\
\hline Trollers-gillnetters & 27 & 0 & 106 & 84 & 82 & 829 & 316 & 0 & 0 & 76 & 0 & 47 & 1 & & 0 & 1 & & 42 & 29 & 1892 \\
\hline Hook and line FADs-gillnetters & 24 & 0 & 32 & 42 & 79 & 436 & 233 & 17 & 0 & 4 & 32 & 0 & 0 & & 32 & & & 718 & 22 & 1847 \\
\hline Hook and long liners & 38 & 0 & 0 & 0 & 0 & 0 & 0 & 305 & 185 & 751 & 63 & 0 & 0 & & 113 & 12 & & 0 & & 1545 \\
\hline Trollers-hook and long liners & 14 & 0 & 0 & 0 & 0 & 0 & 0 & 181 & 170 & 465 & 60 & 0 & 0 & & 0 & & & 0 & 36 & 1241 \\
\hline Total & 767 & 1927 & 17526 & 335 & 789 & 9099 & 2125 & 2258 & 1975 & 3656 & 2677 & 871 & 185 & & \begin{tabular}{l|l|}
209 \\
\end{tabular} & & & 940 & 652 & 363400 \\
\hline
\end{tabular}

As a minimum, three types of economic consequences can be identified. Firstly, fishermen will still inevitably spend a lot of time and incur high fuel costs when fishing on many MFADs rather than fishing on one or two MFADs. The expected benefit in terms of revenue from fishing around MFADs is not realised, since fuel costs are so high the final costs are not very different from trolling line fishing on free-swimming schools. Moreover, fishermen tend to set their MFADs in increasingly distant areas, and this is not compatible with a cost cutting approach (Diaz 2002a,b). Secondly, the density of MFAD installations is considered to be excessive (Guyader et al., unpublished) ${ }^{3}$. This means that FAD costs are too high for the fishermen who set them. Last but not least, excessively high FAD density can lead to aggregation interaction or competition between neighbouring FADs, with a potential loss in local productivity/catchability (Taquet et al. 2011).

In order to mitigate the drawbacks of the non-regulated private FAD system, local professional organisations, with the support of the local administration, decided in 2008 and 2009 to establish a network of collective FADs within a 24-nautical mile limit (Gervain and Diaz, unpublished) ${ }^{4}$. It is difficult at this stage to assess the impact of this network on fishing vessel behaviour and economic performance. Since the Fisheries Information System established in Guadeloupe in 2007 is still operational, and includes fishing trip sampling and socio-economic data collection, it would be possible to look at the evolution of fishing strategies around FADs and related economic performance as a sequel to the present study. Issues regarding the ecological and biological impacts of fishing on

\footnotetext{
${ }^{3}$ Guyader O., Reynal L., Berthou P., Leblond E., Bellanger M., Campéas A., Angin B., Quemener L., Pitel-Roudaut M., Exploring fishermen behaviour around moored FADs: the example of air plane surveys and vessels positioning system in Guadeloupe and Martinique. Communication to the FADs conference, Tahiti, November 2011.

${ }^{4}$ Gervain P., Diaz N., Parc de DCPs collectifs de Guadeloupe (technologie, surveillance, entretien). Communication to the FADs conference, Tahiti, November 2011.
}

MFADs are not considered in this paper, but they should be integrated in fisheries assessment in general (Garcia et al. 2008) and FADs fisheries specifically (Dempster and Taquet 2004). The main catches on MFADs in Guadeloupe are dolphin fish, yellowfin tuna, blue marlin and marginally blackfin tuna, with no reported bycatches of birds or mammals. The commercial species are migratory species with a wide distribution in the Atlantic and Caribbean areas for which Guadeloupe catches are only a fraction of total catches. The first two stocks are fully exploited but ICCAT (2011) recommend a better control or reduction of fishing mortality for blue marlin. This may have an impact on the sustainability of these small scale fisheries in the near future.

Acknowledgements. We would like to especially thank the fishermen who agreed to participate in our data collection programme in Guadeloupe. We would also like to thank the team of IFREMER observers involved in the programme: Carole Erialc, David Beramice, Cédric Jean-Charles, Charly Vincent and Claude Merrien, Patrick Lespagnol, Fabrice Guegan, Mathilde Pitel-Roudaut, Michèle Jézéquel, Fabienne Daurès and Emilie Leblond, for their contribution to the Fisheries Information System in Guadeloupe (SIHG). Funding for the Guadeloupe Fishing Information System was received from the Guadeloupe Region, and the Direction des pêches maritimes et de l'Aquaculture. We extend our thanks also to the Comité Régional des pêches et des élevages marins de Guadeloupe and ASP for their support.

\section{References}

Andro M., Chauvin C., Dorval P. Le Roy Y., 1994, Sécurité et conditions de travail à bord des navires de pêche des îles de la Guadeloupe. Etude IRPM. http://www.magdelesa.eu/

Berthou P., Guyader O., Leblond E., Demanèche S., Daurès F., Merrien C., Lespagnol P., 2008, From fleet census to sampling schemes: an original collection of data on fishing activity for the assessment of the French fisheries. ICES Document CM 2008/K: 12 . 
Boncoeur J., Coglan L., Le Gallic B., Pascoe S., 2000, On the (ir)relevance of rates of return measures of economic performance to small boats. Fish. Res. 49, 105-115.

Blanchet G., Gobert B., Guérédrat J.A. (Eds.), 2002, La pêche aux Antilles, Martinique et Guadeloupe. IRD Editions, Montpellier

Cabrera J.L., Defeo O., 2001, Daily bioeconomic analysis in a multispecific artisanal fishery in Yucatan, Mexico. Aquat. Living Resour. 14, 19-28.

Christy F.T., 1982, Territorial use rights in marine fisheries: definitions and conditions, FAO Fish. Tech. Pap. 227.

Chuenpagdee R., Liguoriand L., Palomares L., Pauly D., 2006, Bottom-up, global estimates of small-scale fisheries catches. Fisheries Center Research Report 14 (8), http://www.fisheries. ubc.ca/publications/.

Defeo O., Castilla J.C., 2005, More than one bag for the world fishery crisis and keys for co-management successes in selected artisanal Latin American shellfisheries. Rev. Fish Biol. Fish. 15, 2-283.

Demanèche S., Merrien C., Vigneau J., Guyader, O., Berthou, P., Lespagnol P., Leblond E., Daurès F., 2008, A new approach to estimate catches and fishing effort of small scale fisheries by sampling fishing trips on-site. ICES CM 2008 / K:14

Dempster T., Taquet M., 2004, Fish aggregation device (FAD) research; gaps in current knowledge and future directions for ecological studies. Rev. Fish Biol. Fish. 14, 21-42.

Failler P., Kroese M. 2011, Socio-economic impact assessment of local FAD fisheries in the South West Indian Ocean, Cofrepêche report, Final version, http://www.swiofp.net/publications/

Daurès F., Rochet M.J., Van Iseghem S., Trenkel V.M., 2009, Fishing fleet typology, economic dependence, and species landing profiles of the French fleets in the Bay of Biscay, 2000-2006. Aquat. Living Resour. 22, 535-547.

Dempster T., Taquet M., 2004, Fish aggregation device (FAD) research: gaps in current knowledge and future directions for ecological studies. Rev. Fish Biol. Fish. 14, 21-42.

Diaz N., 2002a, Etude de la pêche associée aux dispositifs de concentration de poisson ancrés dans le sud de la Basse-Terre en Guadeloupe. Rapp. Institut régional de pêche et de marine.

Diaz N., Doray M., Gervain P., Reynal L., Carpentier A., Lagin A. 2002b, Pêche des poissons pélagiques hauturiers et développement des FADs ancrés en Guadeloupe. FAO Fish. Rep. № 683, suppl., pp. 39-54.

Diaz N., Druault-Aubin K., Frangoudes K., Guyader O., Knockaert C., Le Roy Y., Nelson L., Reynal L., Walters R., 2006. Main results from the work completed by the "Lesser Antilles" working group on the sustainable development of moored FADs fishing and perspectives. http://www.magdelesa.eu/Documentation/ Action-1-Technologie-des-DCP

EC, 2008, Commission decision adopting a multi-annual community programme pursuant to Council Regulation (EC) No 199/2008. Official Journal of the European Union, L60/51.

Fulton E.A., Smith A.D.M, Smith D.C., Van Putten I.E. 2011, Human behaviour: the key source of uncertainty in fisheries management. Fish Fish. 12, 2-17.

Garcia S.M., Allison E.H., Andrew N., Béné C., Bianchi G., De Graaf G., Kalikoski D., Mahon R.L., Orensanz L., 2008, Towards integrated assessment and advice in small-scale fisheries: principles and processes. FAO Fish. Aquac. Tech. Pap. No. 515.

Gobert B., Reynal L., 2002, Les ressources démersales des Antilles et leur exploitation. In : Blanchet G., Gobert B., Guérédrat J.A. (Eds.) La pêche aux Antilles : Martinique et Guadeloupe, IRD Editions, pp. 49-65.
Guyader O., Berthou P., Koustikopoulos C., Alban F., Demaneche S., Gaspar M., Eschbaum R., Fahy E., Tully O., Reynal L., Albert A., 2007, Small-scale coastal fisheries in Europe. Final report of the contract No FISH/2005/10. http://ec.europa.eu/fisheries/ documentation/studies/small_scale_coastal_fisheries_en.pdf.

Guyader O., Berthou P., Koutsikopoulos C., Alban F., Demanèche S. Gaspar M.B., Eschbaum R., Fahy E., Tully O., Reynal L., Curtil O., Frangoudes K., Maynou F., 2013, Small scale fisheries in Europe: a comparative analysis based on a selection of case studies. Fish. Res. 140, 1-13.

Guyader O., Reynal L., Demaneche S., Berthou P., Daurès F., 2008, A fleet-metier based approach of the small scale fishing activity in the French West Indies. Proc. 60th Gulf and Caribbean Fisheries Institute Conference, Punta Cana-Dominican Republic, November 6-10, 2007.

Guyader O., Berthou P., Reynal L., Demanèche S., Bruneau M., Bellanger M., Merrien C., Guegan F., Lespagnol P., PitelRoudaut M., Jézéquel M., Leblond E., Daurès F., 2011, Situation de la pêche en Guadeloupe en 2008. Rapport du projet pilote Système d'Informations Halieutiques Guadeloupe, 2007/2009, http://archimer.ifremer.fr/doc/00086/19689/ ICCAT 2011, Blue marlin and white marlin assessment. 8.2. ICCAT Report. http:// www.iccat.es/en/assess.htm

Leblond E., Demaneche S., Le Blond S., Merrien C., Berthou P., Daurès F., Pitel-Roudaut M., Guyader O., Erialc C., Beramice D., Jean-Charles C. Vincent C., 2010, Activité 2008 des navires de pêche du quartier maritime Pointe-à-Pitre (Guadeloupe). http://sih.ifremer.fr/Contenus-sih/Publications/Syntheses/ Synthese-par-quartier-region-et-facade

Marchal P., Lallemand P., Stokes, K., 2009, The relative weight of traditions, economics, and catch plans in New Zealand fleet dynamics. Can. J. Fish. Aquat. Sci. 66, 291-311.

Reynal L., Taquet M., 2002, Le redéploiement de la pêche antillaise vers les grands poissons pélagiques. In : Blanchet G., Gobert B., Guérédrat J.A., (Eds.), La pêche aux Antilles, IRD Editions, Paris, pp. 73-86.

Rey-Valette H., Cillauren E., David G., 2000, Multidisciplinary assessment of the sustainability of small-scale fishery around anchored FADs. Aquat. Living Resour. 13, 241-252.

Salas S., Chuenpagdee R., Seijo J.C., Charles A., 2007, Challenges in the assessment and management of small-scale fisheries in Latin America and the Caribbean. Fish. Res. 87, 5-16.

Salas S., Gaertner D., 2004, The behavioural dynamics of fishers: management implications. Fish. Fish. 5, 153-167.

Seijo J.C., Caddy J.F., Euan J., 1994, SPATIAL: space-time dynamics in marine fisheries, a software package for sedentary species. FAO Comput. Inf. Series Fish No. 6.

Taquet M., Blanc M., Dagorn L., Filmalter J.D., Fonteneau A., Forget F., Gaertner J.C., Galzin R., Gervain P., Goujon M., Guillotreau P., Guyader O., Hall M., Holland K., Itano D., Monteagudo J.P., Morales-Nin B., Reynal L., Sharp M., Sokimi W., Tanetoa M., Yen Kai S.S., 2011, Artisanal and industrial FADs: A question of scale. Tahiti conference reviews current FAD use and technology. Secr. Pacif. Comm., SPC Fish. Newslett. 136, 35-45. http://www.spc.int/coastfish/en/ publications/bulletins/399-spc-fisheries-newsletter-136.html

Van Iseghem S., Quillérou E., Brigaudeau C., Macher C, Guyader O., Daurès F., 2011, Ensuring representative economic data: survey data-collection methods in France for implementing the Common Fisheries Policy. ICES J. Mar. Sci. 68, 1792-1799. 